\title{
Atypical characteristics of the salmonid pathogen Aeromonas salmonicida
}

\author{
D. McIntosh and B. Austin* \\ Division of Aquaculture, Department of Biological Sciences, Heriot-Watt University, Riccarton, \\ Edinburgh EH14 4AS, UK
}

(Received 28 November 1990; revised 25 February 1991; accepted 5 March 1991)

\begin{abstract}
Incubation of Aeromonas salmonicida at supra-optimal temperatures, i.e. $30-37^{\circ} \mathrm{C}$, resulted in the expression of motility by polar flagella, and changes in sugar fermentation patterns, e.g. loss of acid production from mannitol, loss of the ability to degrade complex molecules (aesculin, DNA, elastin and gelatin), and an increase in antibiotic resistance (notably co-trimoxazole). Motility was enhanced in cultures grown in brain heart infusion broth supplemented with $18 \%$ (w/v) Ficoll.
\end{abstract}

\section{Introduction}

Traditionally, the genus Aeromonas has been divided on the basis of motility, with non-motile species comprising A. media and $A$. salmonicida (Allen et al., 1983; Popoff, 1984). However, the validity of this arbitrary division is now questionable, as motility has recently been reported in A. media (Austin \& Austin, 1990). Moreover, it has been indicated that some strains of $A$. salmonicida are motile, although the flagella patterns have not been discussed (Bryant et al., 1986; Lee, 1987).

In general, the characteristics of $A$. salmonicida have been recorded as a result of incubation of cultures at optimal growth temperatures, i.e. $18-24^{\circ} \mathrm{C}$ (Popoff, 1984). There has been only limited interest in the effects of incubation at supra-optimal temperatures, i.e. $>25^{\circ} \mathrm{C}$. Hahnel \& Gould (1982) reported negligible changes in the biochemical reactions of virulent and avirulent cultures of $A$. salmonicida following incubation at $28{ }^{\circ} \mathrm{C}$. However, it has been indicated that growth at $30^{\circ} \mathrm{C}$, which is regarded as the maximal growth temperature of A. salmonicida (Austin \& Austin, 1987), adversely affects virulence (Ishiguro \& Trust, 1981; Ishiguro et al., 1981). This study has extended earlier work by examining phenotypic changes in $A$. salmonicida following incubation at $\geqslant 30^{\circ} \mathrm{C}$. In particular, emphasis has been placed on examining the expression of motility at supra-optimal temperatures.

\section{Methods}

Bacterial isolates. Five isolates of $A$. salmonicida subsp. salmonicida were examined: AS14 (supplied by Dr G. Dear, Anglian Water

Abbreviation: BHI, brain heart infusion.
Authority, Huntingdon), and LL, NG, S24 and S194 (recovered from the kidney of clinically diseased Atlantic salmon (Salmo salar). Authenticity was verified after Popoff (1984) and Austin et al. (1989). Briefly, the cultures comprised Gram-negative fermentative rods, which produced a diffusible brown pigment on brain heart infusion agar (BHIA; Oxoid), produced catalase and oxidase, and agglutinated with monospecific hyperimmune antiserum to $A$. salmonicida (MonoAs latex agglutination test; BioNor Aqua). Cultures were maintained at $4{ }^{\circ} \mathrm{C}$ on slopes of BHIA and subcultured every 2-3 weeks.

Growth at supra-optimal temperatures. Isolates were initially grown for $48 \mathrm{~h}$ at $25^{\circ} \mathrm{C}$ on L-F agar: $1 \%(w / v)$ brain heart infusion (BHI, Oxoid), $0.5 \%(\mathrm{w} / \mathrm{v})$ yeast extract (Oxoid), $1 \%(\mathrm{w} / \mathrm{v})$ agar no. 3 (Oxoid), $10 \%(\mathrm{w} / \mathrm{v})$ sucrose and $10 \%(\mathrm{v} / \mathrm{v})$ inactivated $\left(56{ }^{\circ} \mathrm{C}\right.$ for $\left.30 \mathrm{~min}\right)$ horse serum (Oxoid) (McIntosh \& Austin, 1988). The ability to grow at supraoptimal temperatures was examined by transferring loopfuls of each culture, grown initially at $25^{\circ} \mathrm{C}$, to fresh L-F agar with incubation at $30^{\circ} \mathrm{C}$ for $48 \mathrm{~h}$. Resultant colonies were subcultured onto fresh plates, and incubated at $35^{\circ} \mathrm{C}$ for $48 \mathrm{~h}$. Inocula were then transferred to fresh $\mathrm{L}-\mathrm{F}$ agar for incubation at $37^{\circ} \mathrm{C}$ for $48-96 \mathrm{~h}$.

Characteristics of $A$. salmonicida grown at different temperatures. Using incubation temperatures of 25,30 and $37^{\circ} \mathrm{C}$, cultures were examined using the tests outlined by Austin et al. (1989). In addition, the isolates were examined for auto-aggregation in distilled water, and for susceptibility to carbenicillin $(100 \mu \mathrm{g})$, cephaloridine $(25 \mu \mathrm{g})$, cotrimoxazole $(25 \mu \mathrm{g})$, sulphamethazole $(200 \mu \mathrm{g})$ and tetracycline $(100 \mu \mathrm{g})($ Mast Laboratories) (after Allen et al., 1977).

Wet preparations from overnight broth cultures (BHI broth, Oxoid)

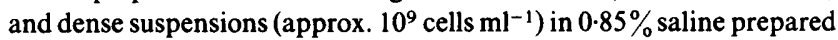
from overnight growth on BHIA and L-F agar were examined at a magnification of $\times 400$ by phase-contrast microscopy to determine the presence of motility. The effects of increased micro-viscosity on the expression of motility were examined after growth (overnight) in BHI supplemented with $18 \%$ (w/v) Ficoll 400DL (Sigma) (after McCarter $e t$ al., 1988). These cultures were diluted $1: 10$ with $0.85 \%$ saline prior to microscopic examination. Motile preparations were subsequently fixed for $1-2 \mathrm{~h}$ in $0.25 \%$ buffered ( $\mathrm{pH} \mathrm{7.4)}$ glutaraldehyde (EMscope), negatively stained with $0.75 \%$ phosphotungstic acid (EMscope), and examined for the presence of flagella with an AEI EM6G transmission electron microscope. 
Table 1. Differences in characteristics of five isolates of Aeromonas salmonicida recorded after incubation at 25, 30 and $37^{\circ} \mathrm{C}$

\begin{tabular}{|c|c|c|c|}
\hline \multirow[b]{2}{*}{ Characteristic } & \multicolumn{3}{|c|}{$\begin{array}{c}\text { Incubation } \\
\text { temperature }\left({ }^{\circ} \mathrm{C}\right)\end{array}$} \\
\hline & 25 & 30 & 37 \\
\hline \multicolumn{4}{|l|}{ Colony and micro-morphology } \\
\hline Production of brown diffusible pigment & + & - & - \\
\hline Motility in BHI & - & $-(1)^{*}$ & + \\
\hline Auto-aggregation of cells & $+(4)^{*}$ & $+(3)^{*}$ & - \\
\hline \multicolumn{4}{|l|}{ Biochemical test } \\
\hline Catalase production & + & - & - \\
\hline \multicolumn{4}{|l|}{ Degradation of: } \\
\hline Aesculin & + & - & - \\
\hline DNA & + & + & - \\
\hline Elastin & + & + & - \\
\hline Gelatin & + & + & - \\
\hline \multicolumn{4}{|l|}{ Production of acid from: } \\
\hline Galactose & + & + & $+(3)^{*}$ \\
\hline Mannitol & + & + & - \\
\hline \multicolumn{4}{|l|}{ Susceptibility to: } \\
\hline Co-trimoxazole $(25 \mu \mathrm{g})$ & + & - & - \\
\hline
\end{tabular}

- Numbers in parentheses refer to the number of positive responses.

\section{Results and Discussion}

All five isolates of $A$. salmonicida grew at $37^{\circ} \mathrm{C}$ when cultured on L-F agar or in BHI. However, there were changes in the characteristics of the organisms at temperatures of $\geqslant 30^{\circ} \mathrm{C}$ (Table 1). For example, pigment production, which is typical of bona fide isolates of $A$. salmonicida subsp. salmonicida (Austin \& Austin, 1987), did not occur at $\geqslant 30^{\circ} \mathrm{C}$. In addition, the ability to produce catalase and to degrade aesculin, DNA, elastin and gelatin was lost at $37^{\circ} \mathrm{C}$. Loss of these enzymic activities, which appeared to be transient insofar as the activities were subsequently detected upon re-incubation of subcultures at $25^{\circ} \mathrm{C}$, may contribute to changes in virulence. Indeed, virulence appears to be diminished when cultures are incubated at $30^{\circ} \mathrm{C}$ rather than at the optimum growth temperature, i.e. $<25^{\circ} \mathrm{C}$ (Ishiguro et al., 1981). In addition, it was observed that all isolates became resistant to co-trimoxazole $(25 \mu \mathrm{g})$ at 30 and $37^{\circ} \mathrm{C}$. Parallel changes in antibiotic sensitivity patterns have been observed by Hahnel \& Gould (1982), who noted that some isolates of $A$. salmonicida became increasingly resistant to novobiocin and sulphisoxazole when incubated at $26^{\circ} \mathrm{C}$ rather than $18^{\circ} \mathrm{C}$.

Following incubation at $37^{\circ} \mathrm{C}$, BHI cultures of all isolates were observed to contain low numbers (approx. $1 \%$ ) of motile cells, which demonstrated a twisting/tum-
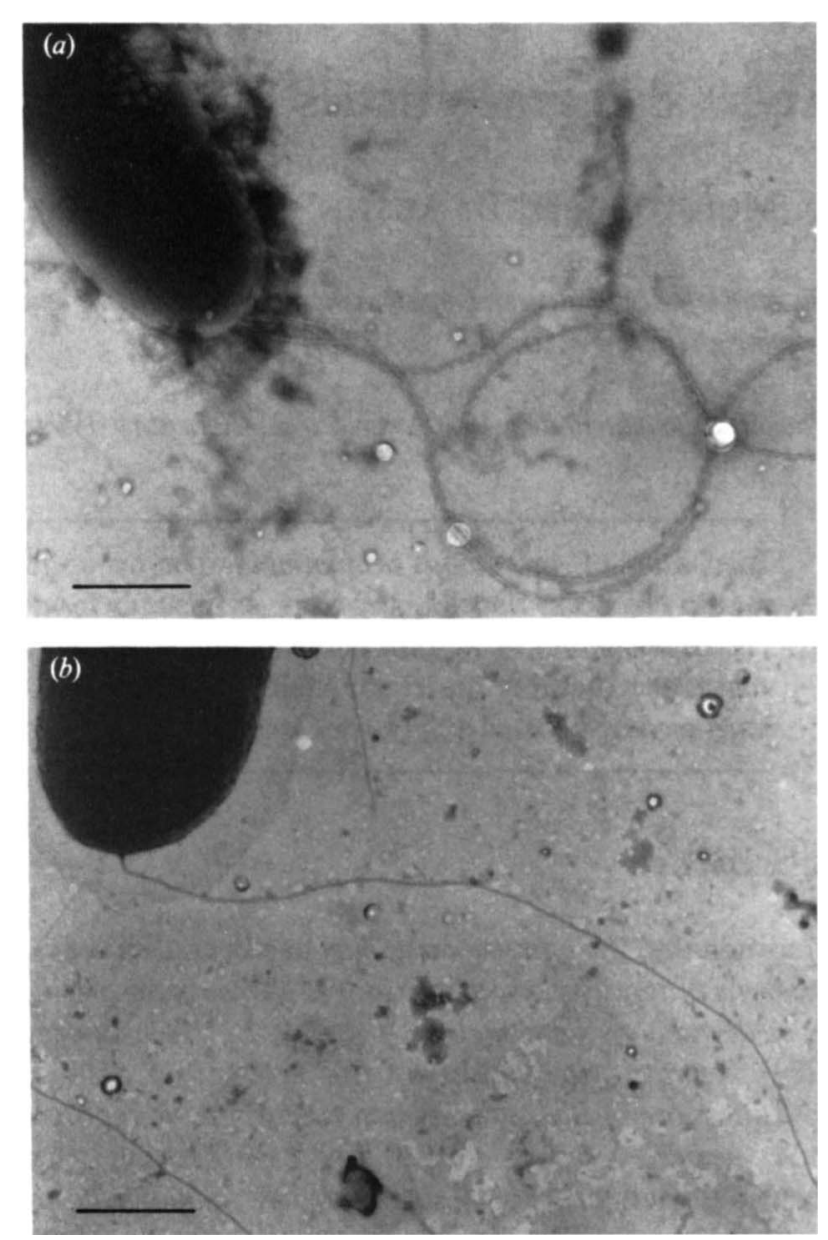

Fig. 1. Negatively stained cells of $A$. salmonicida subsp. salmonicida. (a) Strain S24 grown in Ficoll broth at $30^{\circ} \mathrm{C}$, showing the presence of a tuft of polar flagella. (b) Strain NG grown on L-F medium at $37^{\circ} \mathrm{C}$, showing the presence of a single polar flagellum. Bars, $1 \mu \mathrm{m}$.

bling movement. It should be emphasized that isolate NG was also motile at $30^{\circ} \mathrm{C}$. Examination of suspensions prepared from colonies on L-F agar, when incubated at 30 and $37^{\circ} \mathrm{C}$, also revealed the presence of low numbers of motile cells. However, motility was not observed in any culture in BHI or on L-F agar when incubated at $25^{\circ} \mathrm{C}$. Nevertheless, motility was recorded in cultures which were grown at $25^{\circ} \mathrm{C}$ in BHI supplemented with Ficoll. Using transmission electron microscopy, flagella were observed in suspensions prepared from cultures on L-F agar and in BHI supplemented with Ficoll. Essentially, the nature of the growth medium appeared to influence the thickness of the flagella on the bacterial cells. Thus, thick flagella were produced in the presence of Ficoll. Conversely, only thin flagella were observed around cells grown on L-F agar. For example, in BHI supplemented with Ficoll, each cell of $A$. 
salmonicida S24 demonstrated two or three, apparently sheathed polar-located flagella (Fig. 1a), which resembled those observed on motile cells of $A$. media (Austin \& Austin, 1990). Colonies of $A$. salmonicida NG from L-F agar possessed cells with a single apparently unsheathed, polar-located flagellum (Fig. $1 b$ ). Flagella were not observed on cells from cultures in BHI. Furthermore, flagella were only recorded from freshly prepared negatively-stained specimens. Flagella were not seen on preparations stored overnight at room temperature prior to examination.

The benefit of using Ficoll to enhance the production of flagella agrees with previous work on Vibrio parahaemolyticus, which was observed to produce lateral and polar flagella (McCarter et al., 1988). Thus, it was reasoned that $V$. parahaemolyticus, which normally possesses only polar flagella when grown in liquid medium, produced lateral flagella with physical support, as provided by Ficoll.

Certainly, this study has demonstrated motility in $A$. salmonicida as a result of incubation at supra-optimal temperatures and/or increased micro-viscosity of liquid cultures, i.e. by the addition of Ficoll. Possibly, the possession of flagella represents a different stage of the life cycle, as suggested for $A$. media (Austin \& Austin, 1990). The mechanisms which might induce motility of A. salmonicida in the natural environment are obscure. Perhaps, the presence of mucus on fish surfaces could be mimicking the effects of Ficoll, i.e. by increasing the micro-viscosity.

Helpful assistance with transmission electron microscopy was provided by Mr J. Buchanan.

\section{References}

Allen, D. A., Austin, B. \& Colwell, R. R. (1977). Antibiotic resistance patterns of metal-tolerant bacteria isolated from an estuary. Antimicrobial Agents and Chemotherapy 12, 545-547.

Allen, D. A., Austin, B. \& Colwell, R. R. (1983). Aeromonas media: a new species isolated from river water. International Journal of Systematic Bacteriology 33, 599-604.

Austin, B. \& Austin, D. A. (1987). Bacterial Fish Pathogens: Disease in Farmed and Wild Fish. Chichester Ellis Horwood.

Austin, B. \& Austin, D. A. (1990). Expression of motility in strains of the non-motile species Aeromonas media. FEMS Microbiology Letters 68, 123-124.

Austin, D. A., McIntosh, D. \& Austin, B. (1989). Taxonomy of fish associated Aeromonas spp., with the description of Aeromonas salmonicida subsp. smithia subsp. nov. Systematic and Applied Microbiology 11, 277-290.

Bryant, T. N., Lee, J. V., West, P. A. \& Colwell, R. R. (1986). Numerical classification of species of Vibrio and related genera. Journal of Applied Bacteriology 61, 437-467.

HAHNEL, G. B. \& Gould, R. W. (1982). Effects of temperature on biochemical reactions and drug resistance of virulent and avirulent Aeromonas salmonicida. Journal of Fish Diseases 5, 329-337.

Ishiguro, E. E. \& TRUST, T. J. (1981). Differentiating characteristics of virulent and attenuated strains of Aeromonas salmonicida. In Developments in Biological Standardisation: Symposium on Fish Biologics, Serodiagnostics and Vaccines, vol. 49. pp. 163-168. Edited by D. P. Anderson \& W. Hennessen. Basel: Karger.

Ishiguro, E. E., Kay, W. W., Ainsworth, T., Chamberlain, J. B., Austin, R. A., Buckley, J. T. \& Trust, T. J. (1981). Loss of virulence during culture of Aeromonas salmonicida at high temperature. Journal of Bacteriology 148, 333-340.

LEE, J. V. (1987). Identification of Aeromonas in the routine laboratory. Experientia 43, 355-357.

McCarter, L., Hilmen, M. \& Silverman, M. (1988). Flagellar dynamometer controls swarmer cell differentiation of Vibrio parahaemolyticus. Cell 54, 345-351.

MCINTosh, D. \& Austin, B. (1988). Comparison of methods for the induction, propagation and recovery of L-phase variants of Aeromonas spp. Journal of Diarrhoeal Disease Research 6, 131-136.

Popoff, M. (1984). Genus III. Aeromonas Kluyver and Van Niel 1936, $398^{\mathrm{AL}}$. In Bergey's Manual of Systematic Bacteriology, vol. 1, pp. 545548. Edited by N. R. Krieg \& J. G. Holt. Baltimore: Williams \& Wilkins. 